Орлов Игорь Иванович

ФОРТИФИКАЦИОННЫЕ ОСОБЕННОСТИ УКРЕПЛЕННЫХ ЦЕРКВЕЙ РЕГИОНА ТЬЕРАШ В РУСЛЕ РАЗВИТИЯ ВООРУЖЕНИЯ В XVI-XVII ВВ. (НА ПРИМЕРЕ ЦЕРКВИ СВЯТОГО МАРТИНА

\title{
В БЮРЕЛЕ)
}

В данной статье автором исследуется морфология культового сооружения типа "eglises fortifiees" региона Тьераш XVI-XVII вв. на примере церкви святого Мартина в Бюреле. Впервые в отечественном искусствознании вводятся в научный оборот недоступные ранее российским специалистам иностранные источники, посвященные феномену "eglises fortifiees" региона. На основании переведенных материалов делается вывод о том, что система фортификации церкви Бюреля изначально имела комплексную и логичную оборонительную систему с сохранением тенденции к дальнейшему совершенствованию архитектурно-композиционных схем.

Адрес статьи: www.gramota.net/materials/9/2019/8/35.html

\section{Источник}

\section{Манускрипт}

Тамбов: Грамота, 2019. Том 12. Выпуск 8. С. 173-179. ISSN 2618-9690.

Адрес журнала: www.gramota.net/editions/9.html

Содержание данного номера журнала: www.gramota.net/materials/9/2019/8/

\section{() Издательство "Грамота"}

Информация о возможности публикации статей в журнале размещена на Интернет сайте издательства: www.gramota.net Вопросы, связанные с публикациями научных материалов, редакция просит направлять на адрес: hist@gramota.net 
3. Время и герои. Советский авторский фарфор 1930-1960-х годов: каталог выставки (31 октября 2013 г. - 9 февраля 2014 г.). М.: МГОМЗ, 2013. 68 с.

4. Иванова Е. В. Развитие фарфоровой пластики в 1950-1960-е годы в творчестве ленинградского художникафарфориста А. А. Киселева // Культура и искусство. 2018. № 5. С. 34-40.

5. Каргина 3. А. История становления системы дополнительного образования детей в России: два «золотых периода» // Историко-педагогический журнал. 2013. № 1. С. 89-103.

6. Кречетова Т. Н., Мельцер П. З., Савицкая А. В. Советский художественный фарфор завода имени М. В. Ломоносова: каталог выставки. Л., 1961. VII+254 с.

7. Кривенко И. А. Выставка произведений ленинградских художников: 1917-1957: каталог. Л.: Ленингр. художник, 1958. $112 \mathrm{c}$.

8. Осенняя выставка произведений ленинградских художников, 1958: каталог. Л.: Художник РСФСР, 1959. 94 с.

9. Петрова Н. С. Ленинградский фарфоровый завод имени М. В. Ломоносова. 1944-2004. СПб.: Global View, 2007. 895 с.

10. Хрупкий мир Б. А. Иванова. Коллекция фарфора и фаянса из фондов Елагиноостровского дворца-музея русского декоративно-прикладного искусства и интерьера XVIII-XX веков: каталог выставки. СПб.: ООО «Лайка», 2014. $224 \mathrm{c}$.

11. Центральный государственный архив (ЦГА). Ф. 4965. Оп. 5.

12. ЦГА. Ф. 9688. Оп. 1.

13. Центральный государственный архив литературы и искусства Санкт-Петербурга. Ф. 78. Оп. 10-2.

14. Шведова В. М., Прибульская Г. И., Коробова Э. Б. Осенняя выставка произведений ленинградских художников, 1956: каталог выставки. Л.: Ленингр. художник, 1958. 99 с.

\title{
CHILDHOOD IMAGE IN PLASTIC ART OF LENINGRAD PORCELAIN FACTORY MASTERS IN THE 1950-1960S
}

\author{
Ivanova Ekaterina Vyacheslavovna \\ Herzen State Pedagogical University of Russia, Saint Petersburg \\ degit2406@yandex.ru
}

The period of the 1950-1960s is an important stage in the domestic porcelain industry development, which obtained a mass character under the conditions of new state guidelines. In today's scientific discourse, an exclusively utilitarian attitude to the Soviet mass large-circulation porcelain is replaced by interest and desire to include porcelain history in culturological and art criticism studies. Simultaneously, there is an intensification of collection and exhibition activity using porcelain samples of mass production. At the same time, there is still no corpus of studies devoted to the comprehensive research of porcelain products of factories that actively supported the mass character of artistic industry. In this regard, one of the topical tasks of modern art criticism is the research of the assortment of interior plastic art of the little-studied Leningrad Porcelain Factory of the 1950-60s. Using the example of sculptural products of Leningrad artists of the factory, the author conducts a comparative-contrastive analysis, during which the main thematic and plot groups are singled out, and an analysis of composition solutions characteristic of the representation of a specific topic - childhood - is conducted.

Key words and phrases: Soviet porcelain; interior plastic art; Leningrad Porcelain Factory; children's images; childhood image in porcelain plastic art; Tamara Andrianovna Fedorova; Lev Naumovich Smorgon; Leningrad porcelain of the 1950-1960s.

УДК 72.012 .03

https://doi.org/10.30853/manuscript.2019.8.35

Дата поступления рукописи: 05.05.2019

В данной статье автором исследуется морфология культового сооружения типа "еglises fortifiees" региона Тьераш XVI-XVII вв. на примере цеерки святого Мартина в Бюреле. Впервые в отечественном искусствознании вводятся в научный оборот недоступные ранее российским специалистам иностранные источники, посвященные феномену "eglises fortifieеs” региона. На основании переведенных материалов делается вывод о том, что система фортификаџии церкви Бюреля изначально имела комплексную и логичную оборонительную систему с сохранением тенденции к дальнейшему совериенствованию архитектурно-композиционных схем.

Ключевые слова и фразы: укрепленные церкви; Эна; Арденны; церковь святого Мартина (Saint-Martin); Бюрель (Burelles); испано-французские войны; фортификация; культовые сооружения.

Орлов Игорь Иванович, д. искусствоведения, профессор

Липеикий государственный технический университет

igorlov64@mail.ru

\section{ФОРТИФИКАЦИОННЫЕ ОСОБЕННОСТИ УКРЕПЛЕННЫХ ЦЕРКВЕЙ РЕГИОНА ТЬЕРАШ В РУСЛЕ РАЗВИТИЯ ВООРУЖЕНИЯ В XVI-XVII ВВ. (НА ПРИМЕРЕ ЦЕРКВИ СВЯТОГО МАРТИНА В БЮРЕЛЕ)}

В последние десятилетия в отечественном искусствоведении наблюдается устойчивая тенденция к исследованию региональных особенностей культового и светского искусства средневековой Европы. Хотя в зарубежной науке существует довольно значительное число работ, посвященных романо-готическому 
искусству вообще и Франции в частности, целостному изучению особенностей культовой архитектуры “eglises fortifiees" уделено недостаточно внимания, а в отечественной медиевистике эта проблема серьезно не изучалась со времен дореволюционного периода. С историографией данной проблемы на русском языке подробно можно ознакомиться в монографиях автора [3, с. 4; 5, с. 9]. Актуальность настоящей статьи обусловлена необходимостью историко-искусствоведческого исследования одного из наиболее интересных феноменов европейской культуры культовых сооружений “eglises fortifiees” региона Тьераш Северной Франции на примере церкви святого Мартина (Saint-Martin) в Бюреле (Burelles). Научная новизна данной статьи состоит во введении в научный оборот отечественной медиевистики новых иностранных источников и результатов исследований коллег из «Группы археологических изысканий Тьераша» (GRAT), переведенных и впервые опубликованных автором.

Целью статьи является на основании результатов исследований коллег из «Группы археологических изысканий Тьераша» (GRAT) фортификации церкви Бюреля доказать тот факт, что морфология культовых сооружений региона Тьераш (Эна, Арденны) не носила спонтанный характер. Напротив, она изначально представляла собой комплексную и логичную оборонительную систему, способную адекватно противостоять внезапным атакам противника.

Для достижения поставленной цели в статье определены следующие задачи исследования: во-первых, показать особенности исторического фона XVI-XVII вв. в той степени, в какой они влияли на сложение типологии укрепленных церквей “eglises fortifiees” региона Тьераш (Эна, Арденны); во-вторых, изучить расположение элементов фортификационной архитектуры XVI-XVII вв. в организации пространства церкви СенМартен в Бюреле; в-третьих, на примере изучения секторов наблюдений и обстрела группой археологических изысканий Тьераша (GRAT) показать взаимосвязь церкви в Бюреле с аналогичными культовыми сооружениями “eglises fortifiees” соседних населенных пунктов Прис, Гронар, Вервен, Ари и Бомон, с тем чтобы доказать тезис, заявленный целью статьи.

В эпоху позднего Средневековья на севере Франции укрепленные церкви “eglises fortifiees” получают как бы «второе рождение» в регионе Тьераш, расположенном на территории двух департаментов Эна (Aisne) и Арденны (Ardennes). Около шестидесяти сохранившихся до наших дней религиозно-фортификационных сооружений сосредоточены в различных местечках вокруг коммуны Вервен (Vervins) примерно в 175 километрах к северовостоку от Парижа. Широко распространенное среди ряда историков мнение ранее датировало эти укрепленные церкви периодом Столетней войны, хотя большинство из них было построено уже в XVI-XVII вв., когда пограничная область Тьераш оказалась в центре ожесточенных военных конфликтов между Францией и Испанией. Позднее этот же регион стал ареной кровавых религиозных войн, Тридцатилетней войны и Фронды, когда с 1515 по 1715 гг. здесь шла практически постоянная 200-летняя война [2, с. 174].

Весьма продолжительное время в зарубежной и отечественной истории и искусствоведении считалось, что главной функцией укрепленных церквей “eglises fortifiees” Франции вообще и непосредственно региона Тьераш в частности была защита сельского населения, укрывавшегося там во время внезапных нападений врагов. Таким образом, вся фортификационно-оборонительная суть этих уникальных культовых сооружений как бы сводилась только лишь к пассивной роли «убежища». Исходя из этого предположения, искусствоведы, археологи и историки совершенно пренебрегали сравнительным анализом самих фортификационных систем (их отдельных элементов) укрепленных церквей региона. В отечественной науке эта проблематика специально не рассматривалась и во времена советского периода, и после него, что привело к возникновению многочисленных лакун, затрудняющих воссоздание объективной картины западноевропейского средневекового социума [3]. Более подробно зарубежная и отечественная библиография проблемы укрепленных церквей “eglises fortifiees” Франции рассмотрена в монографиях автора [4, с. 504].

История Франции всей первой половины XVI столетия отмечена ожесточенными Итальянскими войнами (1494-1559), которые были обусловлены соперничеством двух наиболее крупных европейских монархий: Королевства Франции и империи Габсбургов, включавшей при Карле V большую часть тогдашней Европы [1, с. 174]. Первоначально французские монархи Карл VIII, его приемник Людовик ХI в 1494 г. и Людовик XII в 1499 г. вели военные действия на территории Италии. Позднее, в годы правления Франциска I (1515-1547), основные сражения четырех «итальянских» кампаний (1521-1525; 1527-1529; 1536-1538; 1542-1544) велись уже на территории самой Франции [2, с. 175]. Так, в течение всего лета 1536 г. одна армия Карла V воевала в Провансе, а еще две имперские армии захватили Пиардию и Шампань. Позже в 1542 г. войска императора Карла V в очередной раз оккупировали часть французской территории и продвинулись вглубь до Шато-Тьери, где имперские армии были остановлены французскими войсками, срочно отозванными из Италии [1, с. 176]. Во избежание подобных рейдов во время военных действий 1542-1543 гг. по инициативе Франциска I была развернута серьезная программа по реконструкции старых и возведению новых крепостей, например, таких, как Гиза (Guise), Шатле (La Catelet), Ла-Шапель (La Capelle). В целях создания отдельных опорных пунктов между крепостями также проводились фортификационные работы укрепленных церквей "eglises fortifiees" региона [9, p. 13]. После смерти Франциска I в 1547 году его сын Генрих II вновь начал военные действия против германо-испанской империи в 1552 г. Война велась с переменными успехами, провинция Тьераш была оккупирована имперскими армиями, причем город Вервен (Vervins) был полностью разрушен и сожжен войсками Марии Венгерской, сестры и союзницы Карла V. В 1557 г. испаногерманская армия Филиппа II пытается захватить Рокруа (Rocroi), затем через брешь между Шиме (Chimay) и Трелоном (Trelon) вторгается на территорию Франции в Этрене (Etroeungt), направляясь через Ла-Шапель 
и Гиз, осаждает Сен-Кэнтен (Saint-Quentin) [Ibidem]. Сохранились подробные мемуары нотариуса Де Марля, который описывает беспорядки, учиненные имперскими ландскнехтами, швейцарцами, испанцами или солдатами короля в этом уголке Тьераша в 1635-1653 гг. [11, p. 56].

Длительное время среди историков общепризнанным считался тот факт, что главной функцией укрепленных церквей “eglises fortifiees” региона Тьераш была защита сельского населения, стекавшегося туда по звуку набата и беспомощно наблюдавшего за разорением их хижин. Таким образом, вся фортификационнооборонительная суть этих оригинальных сооружений как бы сводилась только лишь к пассивной роли. Исходя из этого предположения, археологи и историки совершенно пренебрегали сравнительным анализом самих фортификационных систем укрепленных церквей “eglises fortifiees” региона. Однако со временем исследователям становилось понятно, что сооружение столь дорогостоящих универсальных сооружений военного и культового назначения в сельской местности, при довольно ограниченных финансовых и материальных ресурсах тогдашнего общества, не могло носить случайного характера. Поэтому, во многом благодаря стараниям Пьера Досса, президента Археологического общества Вервена и Тьераша, в 1974 г. были проведены специальные исследования с целью установления степени оборонительных возможностей фортификационных сооружений “eglises fortifiees” региона. В качестве экспериментального образца для проведения такого исследования была выбрана наиболее типичная и хорошо сохранившаяся укрепленная церковь Бюреля (Burelles), изображенная на Рисунке 1 [9, p. 50]. Группа специалистов-историков GRAT (Группа археологических изысканий Тьераша), проводившая эти исследования, выполнила точную копию плана всего церковного здания, его укреплений и тщательно изучила оборонительную систему.
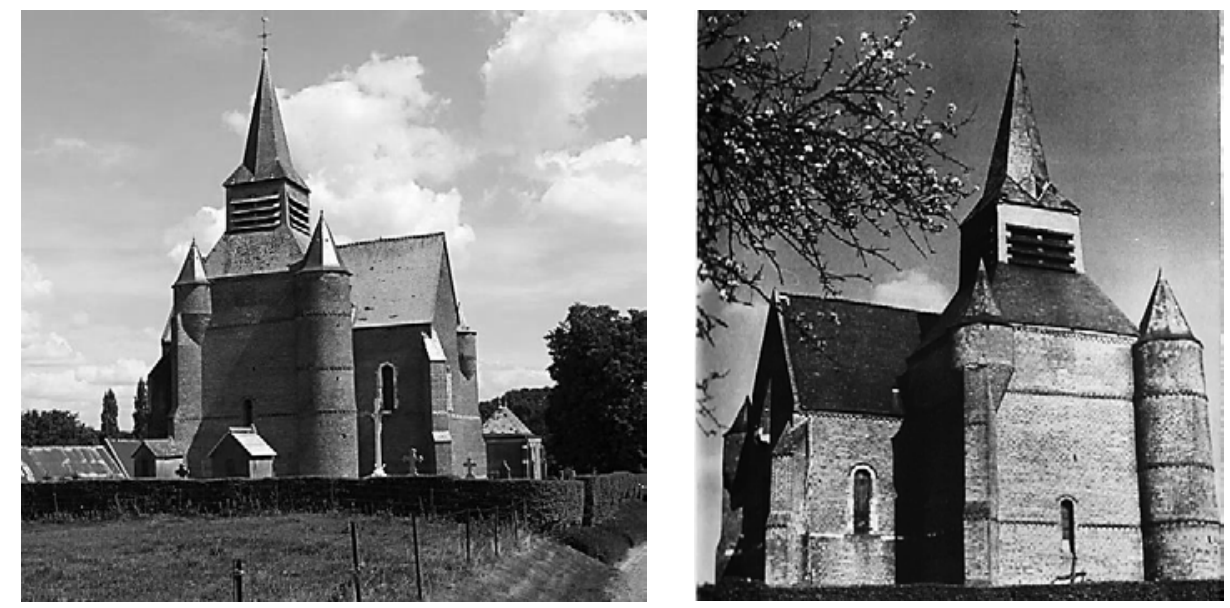

Рисунок 1. Церковь святого Мартина (Saint-Martin) в Бюреле (Burelles) [9, p. 49]

Укрепленная церковь святого Мартина (Saint-Martin) в местечке Бюрель (Burelles) в плане имеет форму перевернутого латинского креста (подножие которого обращено на запад в сторону церковной паперти). Все здание церкви в целом смотрится весьма гармонично и пропорционально, хотя представляет собой две части, сооруженные из разного материала, которые можно различить с первого взгляда. Хоры церкви, относящиеся к первоначальной культовой (сакральной) части церковного здания, сложены из белого камня отменного качества. Фортификационная часть церкви (собственно крепость), детальное изучение которой нас интересует, полностью возведена из глиняного кирпича, причем эта укрепленная часть церкви представляет собой однородный ансамбль из секций-корпусов различных архитектурных конструкций, логично связанных и взаимодополняющих друг друга (Рисунок 1). Время постройки укрепленной части церкви точно неизвестно, однако сравнительное стилистическое исследование здания определяет существование кирпичной кладки уже в начале XVII века, примерно в 1610-1620 гг. Достоверным текстом, описывающим реконструкцию этого культового сооружения, является контракт, подписанный 19 октября 1664 г между коммуной Бюреля и каменщиком Де Сийи, о проведении реставрационных работ форта-церкви: «В первую очередь нужно укрепить башню, поднять выше стены оной, чтобы подпереть уложенную кровлю, и до обвязки... две кладки кирпича, и внутри камня или булыжника, на усмотрение подрядчика. Нужно восстановить башню в хорошем и удовлетворительном состоянии, особенно барбакан указанной башни. Нужно сделать заново или, по крайне мере, продолжить подправлять начатый камин в вышеуказанной башне и возвести его только до высоты стены и обвязки...» [Ibidem, p. 57]. Публикуя текст этого контракта, найденного среди протоколов нотариуса Вервена, историк Эдуар Пьетт уточнял в 1878 году: «Выполняемые работы имели целью улучшение внешнего обустройства церкви и усиление ее оборонной мощи... Не это ли доказательство, что наши укрепленные церкви реально несли службу в последних войнах (1635-1658) и остались в сознании сельских жителей защитницами их будущего?» [Ibidem]. Единство замысла всего сооружения (культового и фортификационного), качество его исполнения и превосходное состояние сохранности в придачу к строгой красоте этой религиозно-военной архитектуры XVI века явно выделяют церковь Бюреля среди всех укрепленных церквей региона Тьераш (с 1931 г. охраняется государством как исторический памятник). 


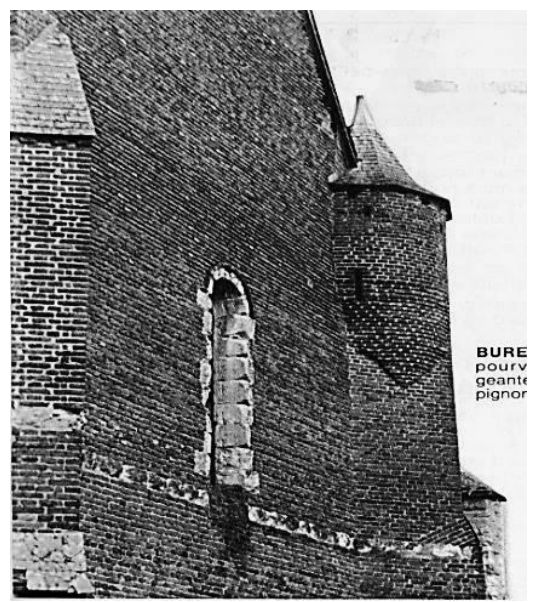

Рисунок 2. Угловая сторожевая башня над окном южного трансепта иеркви святого Мартина (eglise Saint-Martin) в Бюреле (Burelles) [9, p. 51]

При внешнем осмотре церкви мы сразу же видим ее грозные внешние формы, воспринимая их как бы с позиции врагов, осаждающих здание. Но для того чтобы понять военные возможности здания, необходимо исследовать церковь изнутри, чтобы узнать изначальную организацию ее оборонительной системы. И здесь мы сразу обнаружим элементы активной обороны, поскольку портик (паперть), расположенный на нижнем этаже башни, и трансепт (средокрестие) церкви снабжены серией из 17 бойниц-амбразур, расположенных на высоте человеческого роста, одна из которых изображена на Рисунке 3. Причем если брать в расчет видимые следы от заложенных позднейшей кладкой бойниц на внешней стороне стены, которые скрывает штукатурка, становится ясно, что изначально количество бойниц было намного больше. В алтарной части церкви мы видим еще 12 амбразур, тщательно расчищенные аббатом Менаром, бывшим приходским кюре, которые демонстрируют огневую мощь всего церковного ансамбля. Поднимаясь по винтовой лестнице в башне на верхние этажи здания, мы вновь встречаем серию из 14 амбразур, расположенных на одинаковом расстоянии друг от друга.

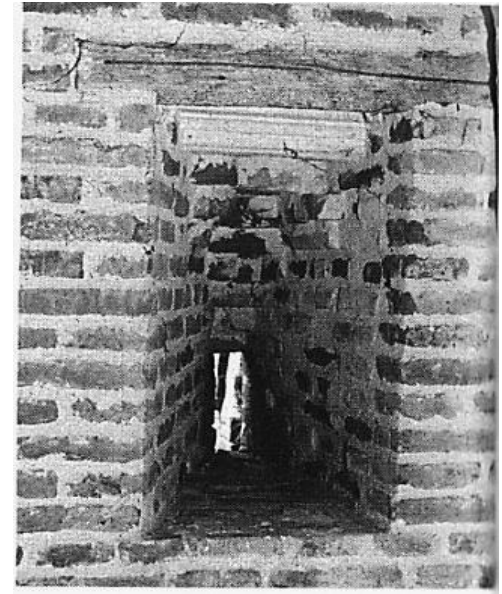

Рисунок 3. Угловая бойница над окном южного трансепта $[9$, p. 56]

Свод второго этажа башни, как и сама башня, выполнен из обожженного кирпича. Внутри второго этажа расположено помещение довольно скромных размеров 5 х 5 м, освещенное проемом-амбразурой с видом на юг, которая показана на Рисунке 2. Внутреннее пространство также снабжено еще 4 бойницами, распределенными по трем сторонам башни [Ibidem, p. 51]. Пройдя через колокольню, мы попадаем в верхнюю часть трансепта, где расположена более просторная комната (16 х 6 м), видимо, убежище для населения, и т.н. «комната-сейф» для хранения ценностей. Развертка стен комнаты поддерживает высокую несущую каркасную конструкцию с выступающими навесными бойницами на северном щипце (Рисунок 1). С этого этажа есть также доступ к двум угловым сторожевым башням, имеющим собственные бойницы-амбразуры. На юго-восточной башне церкви также расположена большая комната-убежище, которую местные жители называют «еврейской комнатой», хотя достоверно неизвестно, какое историческое событие послужило поводом или основанием для такого названия (Рисунок 4).

В ходе осмотра интерьера церкви было обнаружено всего 50 бойниц, причем их расположение во всех частях постройки (в основании стен трансепта, в лестничной башне, на всех этажах башни, в угловых сторожевых башнях) явно показывает, что это прежде всего огневые точки. Наиболее интересные бойницы-амбразуры расположены в трех угловых сторожевых башенках (бартизанах), которые можно увидеть на Рисунке 2. 
Построенные на вершине церковной стены, они кажутся задуманными специально, чтобы обеспечивать и функцию наблюдения, и функцию обстрела. Исследователи из GRAT специально проверяли контролируемые ружейным огнем пространства и нанесли на карту результаты своих наблюдений (Рисунок 5) [Ibidem, p. 53].

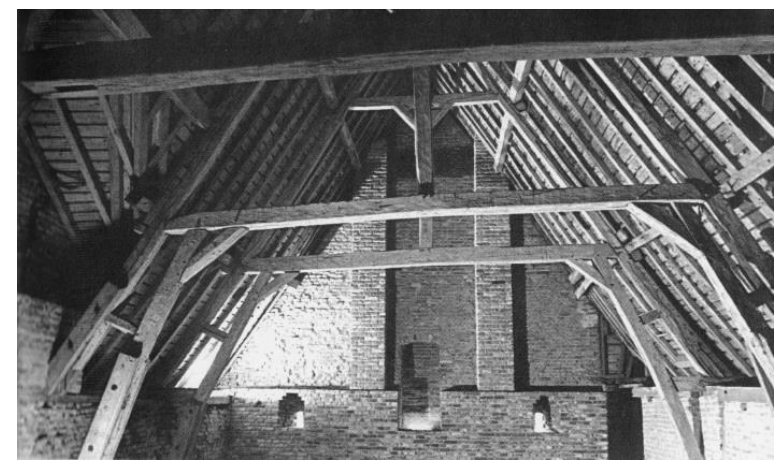

Рисунок 4. «Еврейская комната» иеркви в Бюреле (Burelles) [9, p. 57]

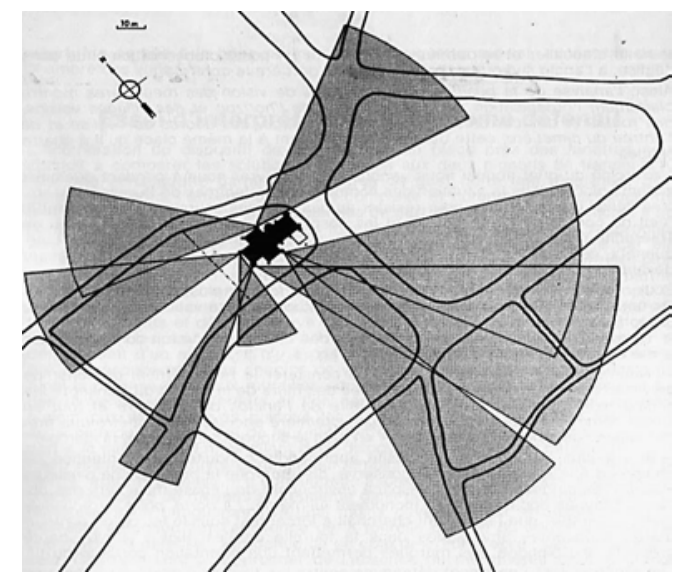

Рисунок 5. Схема обстрела окрестностей церкви в Бюреле.

Поле видимости и сектора обстрела из основных амбразур башенки и угловых сторожевых башен [9, p. 53]

Особо стоит отметить тот факт, что городок Бюрель занимает весьма важное положение на перекрестке естественного пути «восток - запад» вдоль долины Брюны и пути «север - юг», ведущего от Вервена к Лану через Бомон-сюр-Сер. Долина Брюны отмечена многочисленными деревушками, соединяющими две параллельные долине дороги с обеих сторон реки. Ближайшие деревни - это Прис, Ури, Гронар и Ари, причем каждая из них располагает своей собственной укрепленной церковью “eglises fortifiees”. Расположившись перед амбразурами угловых сторожевых башен, можно обстреливать все вышеперечисленные участки ландшафта: долину Брюны, дороги, ведущие из Бюреля в Прис, Гронар, Вервен, Ари, Бомон. Некоторые особо значимые «точечные цели», такие, как перекресток дорог вдоль правого берега Брюны и дороги из Вервена в Бомон, простреливаются особенно хорошо [Ibidem]. Укрепленная церковь городка Прис, являющаяся частью общей оборонительной системы региона, также отлично видна из амбразуры северо-западной угловой сторожевой башни. Наиболее опасный участок обороны, проход со стороны сельского кладбища, который просматривается и простреливается сразу с семи точек (амбразур), причем 2 амбразуры расположены в угловых сторожевых башнях, 4 амбразуры - в «лестничной» башне, и последняя амбразура расположена в церкви с юго-западного угла южного трансепта, позади контрфорса. Таким образом, анализ расположения и секторов обстрела бойниц-амбразур церкви Бюреля четко показывает площади наблюдения за соседними деревнями, дорогами и перекрестками, окрестностями самой церкви и проходом на приходское кладбище, которое существует тут четыре века (Рисунок 5).

Необходимость защитникам церкви-крепости контролировать не только отдаленные пространства, но и ближайшие подходы к церкви была обусловлена стремительным развитием огнестрельного оружия на протяжении всего XVI в. [12]. Именно в период «итальянских войн» происходит окончательное формирование специальных подразделений пехоты и кавалерии, вооруженных пушками, аркебузами, мушкетами и пистолетами. В этот период артиллерия окончательно стала подразделяться на полевую, непосредственно приданную войскам, и осадную. Пушки получают колесные лафеты на конной тяге, что значительно упрощает их передвижение и усиливает огненную мощь пехотинцев и кавалеристов [1, с. 320]. Именно по этой причине при возведении фортификационных сооружений особое внимание всегда уделялось планировке секторов обстрела и защите т.н. «мертвых зон». На Рисунке 5 хорошо видно пересечение (сопоставление) полей видимости (секторы обстрела) бойниц-амбразур, расположенных у подножия стен башни и трансепта. Углы 
«мертвой» зоны исчезают на границе ограды кладбища так, как будто эта граница образовывала первый пояс укреплений или, возможно, первую линию обороны, защищающую, как можно предположить, скот, согнанный в одно место. В ходе тщательного обследования сохранившейся системы обороны Бюреля можно заметить присутствие многочисленных бойниц, направленных не в сторону окружающего церковь пространства, но к более близким целям. Например, ворота всегда считались особо уязвимой частью обороны, которую атакующие стремятся взять в первую очередь. Ворота в Бюрель находятся под прицелом двух амбразур-бойниц, расположенных с обоих флангов лестничной башни, причем самая высокая представляет явно выраженный скат бруствера, обеспечивающий точное направление стрельбы [10, p. 54]. Система ближней обороны позволяет защитить окна церкви от штурма. Западное окно северной части средокрестия трансепта простреливается из бойницы караульного помещения, причем форма этой бойницы отличается от формы других бойниц. Она узкая и высокая, а ее облицовка обладает серией выступов, отмечающих прицельное направление стрельбы в сторону церковного окна, которое она прикрывает с фланга. Над окном северной фронтонной стены возвышается выступающая навесная бойница «машикули», сектор обстрела которой защищает подход к помещению-убежищу, расположенному над трансептом. Западное окно южной части средокрестия трансепта находится под огнем бойницы, расположенной у подножья лестничной башни. Окно южной фронтонной стены простреливается из бойницы у основания стены юго-восточной угловой сторожевой вышки, доступной из т.н. «еврейской комнаты» [Ibidem, p. 55].

На юге угловая сторожевая башня, снабженная проемами для постов визуального наблюдения и оповещения, имеет глубокую бойницу; на севере фортификационный ансамбль более сложный и состоит из угловой сторожевой башни, выступающей навесной башенки с двумя бойницами-амбразурами, расположенными по обеим ее сторонам (Рисунок 2). Это местоположение амбразур нам кажется важным, так как оно подтверждает тот факт, что при необходимости интенсивное ведение огня возложено на углубленную бойницу юговосточной угловой сторожевой башни. Теснота этой угловой башни совершенно не позволяет находиться в ней большому числу защитников, что несколько затрудняет ведение интенсивной стрельбы. Защита двух противоположных стен трансепта обеспечивается довольно разными средствами, и можно лишь удивляться, что не использовались одни и те же устройства, хотя цели обороны идентичны как с точки зрения их природы, так и с точки зрения их расположения по отношению к комнате-сейфу. Использование вертикального прикрытия фланга, менее разработанного на южной части средокрестия трансепта, возможно, оправдано существованием угловой башенки донжона, которая обеспечивала лучшую ближнюю оборону с этой стороны крепости. Так, одно средство фортификации компенсировало другое, и эти факты извиняют отсутствие бойниц в большом высоком зале на южной стороне. Лестничная башенка, снабженная многочисленными амбразурами для стрельбы, образует особое место, в котором могла быть сфокусирована вся активная ближняя оборона, особенно в первые моменты атаки, при входе на кладбище. Организация ближней обороны может быть истолкована как применение классических правил прикрытия флангов: башенка прикрывает донжон, донжон обеспечивает фланг трансепта, который, в свою очередь, поддерживает с флангов хоры. Каждая грань здания действительно укрыта от перекрестного огня, как фронтального, так и бокового. Взаимодополняемость различных частей крепости при обороне очевидна [12, p. 135]. Можно сказать, что существует снижение необходимости защиты с флангов трансепта, донжона и башенки, поскольку распределение бойниц, расположенных на высоте человеческого роста у основания стен, четко указывает на эту оборонительную структуру. Некоторые из этих низких бойниц-амбразур позволяют вести одновременно фронтальный, косоприцельный (навесной) огонь и огонь с флангов. Осталось одно слабое место обороны - торцевые (фронтонные) стены, которые закрывают с юга и с севера трансепт, они могут быть защищены с тыла только с помощью фронтальных бойниц, оставляя т.н. «мертвый угол»- непростреливаемый участок, они наиболее уязвимы. Непонятно, по какой причине строители изначально этого не предусмотрели. Видимо, поэтому стало необходимо усилить оборону, ликвидировав эти мертвые углы. Решено было установить наверху стены особые оборонительные устройства - навесные бойницы, позволяющие вести вертикальный огонь для прикрытия флангов. Поэтому логично объяснимо присутствие выступающей навесной бойницы с севера трансепта и бойницы для навесной (почти вертикальной) стрельбы с юга, у основания угловой сторожевой башни. Тройной фортификационный синтез: топографический (церковь с людьми и ее естественное окружение), архитектурный (оборонительные сооружения, их тип и распределение) и функциональный (наблюдение, пассивная и активная оборона) - позволяет нам определить главные принципы фортификационной системы церкви Бюреля $[11$, р. 56]. Следует предположить, что 3-4 часовых было вполне достаточно, чтобы обеспечить полное наблюдение за местностью, а примерно 6 человек могли защищать входные проемы (дверь и окна) в случае внезапной атаки неприятеля. Грамотно продуманная система расположения амбразур позволяла при наличии всего лишь 30-40 единиц огнестрельного оружия (аркебуз или мушкетов) держать необходимую оборону здания. Остается нерешенным лишь риторический вопрос: располагала ли в те времена коммуна Бюреля 40 мушкетами, аркебузами и пистолетами, или здесь присутствовал какой-либо королевский гарнизон [7, p. 30]?

Заключение. На основании изложенного в статье материала можно с большой степенью вероятности предположить следующее. Вследствие бурного развития огнестрельного оружия XVI-XVII вв., в эпоху постоянных войн с 1515 по 1715 гг. на границе Пикардии в регионе Тьераш (Эна, Арденны) возникает необходимость специально укреплять культовые христианские сооружения. В результате чего они становились опорными фортификационными пунктами в общей системе обороны северных границ Франции [6]. Во-вторых, в ходе анализа отдельных элементов церковных укреплений был выявлен неоспоримый факт: система фортификации 
церкви Бюреля демонстрирует нам комплексную и логичную оборонительную систему, способную адекватно противостоять ограниченным военным контингентам в случае их внезапной атаки. Местоположение амбразур на хорах церкви, трансепта, лестничной башни, башенок-бартизанов и угловых сторожевых башен явно соответствует всем правилам защиты фронтов и флангов, свойственных любому чисто военному сооружению XVI-XVII вв. Десятки амбразур-бойниц, расположенных на всех уровнях церковного здания, являются одновременно и наблюдательными постами, и огневыми точками, обеспечивающими визуальный контроль и огневой обстрел линии горизонта и соседних церквей, дорог, ведущих к деревне, их перекрестков, подходов к самой церкви, а также обеспечивают контроль и управление первой линией обороны, образованной изгородью церковного кладбища. Другие элементы фортификации церкви Борель, такие, как выступающие навесные бойницы «машикули», прикрывают как фронтальным настильным, так и навесным, перекрестным огнем ворота и окна церкви [10]. В-третьих, изучение секторов наблюдений и обстрела группой археологических изысканий Тьераша (GRAT) доказывает, что оборонительная система укрепленной церкви Бюреля хорошо продумана, цельна, логична и оригинальна. Она обеспечивает все функции, которые необходимы для реализации боевых возможностей настоящей крепости: разведка наблюдением горизонта и дорог, ведущих к деревне и церкви; ближняя оборона окрестностей церкви и подступов к ней; внутреннее обустройство здания: укрытие, комната-сейф и караульное помещение с камином. Путем наблюдений и огневой поддержкой совместно с аналогичными культовыми сооружениями “eglises fortifiees” соседних населенных пунктов Прис, Ури, Гронар, Вервен, Ари и Бомон обороняющиеся могли полностью контролировать участки прилегающего ландшафта: долину Брюны, перекресток дорог вдоль правого берега Брюны и дороги из Бюреля в Прис, Гронар, Ари, а также из Вервена в Бомон [9, p. 53]. Таким образом, становится очевидным тот факт, что такая логичная система укреплений приходской церкви в Бюреле - отнюдь не единственная в своем роде. В силу своей особой значимости укрепленные церкви “eglises fortifiees” региона Тьераш изначально получали тенденцию к дальнейшему совершенствованию архитектурно-фортификационных схем. Как мы отмечали ранее в своих публикациях, подобные фортификационные системы или похожие фортификационные решения в той или иной форме встречаются в большинстве укрепленных церквей “eglises fortifiees” региона Тьераш [6, с. 136].

Список источников

1. Дельбрюк Г. История военного искусства. Средневековье. Новое время / пер. с нем. Смоленск: Русич, 2003.632 с.

2. История Франции: в 3-х т. / ред. А. З. Манфред. М.: Наука, 1972. Т. 1. 357 с.

3. Орлов И. И. Антикатарские «крепости веры»: монография. Saarbrucken: LAP, 2012. 437 с.

4. Орлов И. И. Богословие в камне. Укрепленные церкви Окситании X-XV вв.: монография. М.: Изд-во МГХПА им. С. Г. Строганова, 2016. $516 \mathrm{c.}$

5. Орлов И. И. Культовая архитектура Окситании “eglises fortifiees” XIII-XV вв.: монография. Липецк: Издательство ЛГТУ, 2013. 338 с.

6. Орлов И. И. Фортификационные особенности сложения укрепленных церквей на севере Франции в XVI-XVII вв. // Исторические, философские, политические и юридические науки, культурология и искусствоведение. Вопросы теории и практики. 2018. № 2 (88). С. 132-136.

7. Garel J. Églises fortifiées de la Thiérache (coll. Itinéraires et découvertes, éd. Elta). Paris, 1976. 32 p.

8. Lemasson A. Les églises fortifiées de la Thiérache: trente lithographes originales. Vervins, 1938. $11 \mathrm{p}$.

9. Meuret J.-P. Guide des eglises fortifiees de la Thierache. Vervins, 1988. 64 p.

10. Meuret J.-P. Les eglises fortifiees de la Thierache. Vervins, 1976. 63 p.

11. Meuret J.-P. Redécouverte et sauvegarde du patrimoine communautaire des pays picards: Les églises fortifiées de la Thiérache // Picardie Information. 1978. № 32. P. 55-66.

12. Poujol R. Les églises fortifiées de la Thiérache. Monographies des villes et villages de France. Vervins: Societe Archeologique et Historique de Vervins et de la Thierache, 1993. 140 p.

\title{
FORTIFICATION FEATURES OF THIÉRACHE FORTIFIED CHURCHES IN LINE WITH THE ARMS DEVELOPMENT OF THE XVI-XVII CENTURIES (BY THE EXAMPLE OF ST MARTIN'S CHURCH IN BURELLES)
}

\author{
Orlov Igor Ivanovich, Doctor in Art Criticism, Professor \\ Lipetsk State Technical University \\ igorlov64@mail.ru
}

The article examines the morphology of Thiérache religious constructions "eglises fortifiees" of the XVI-XVII centuries by the example of St Martin's church in Burelles. For the first time in the domestic art criticism, the author introduces previously unavailable foreign sources devoted to the "eglises fortifiees" phenomenon into scientific use. Analysing the translated materials, the researcher concludes that the church of Burelles initially had a complex and logical fortification system preserving the tendency to further improvement of architectural and compositional schemes.

Key words and phrases: fortified churches; Aisne; Ardennes; St Martin's church; Burelles; Franco-Spanish wars; fortification; religious constructions. 